\title{
Rambutan seed germination: temperature and storage
}

\author{
Renata Aparecida de Andrade, Amanda Garcia Bagatim, Guilherme Nacata
}

São Paulo State University, Jaboticabal, SP, Brazil

Corresponding author, e-mail: reandrad@fcav.unesp.br

\begin{abstract}
The objective of this study was to verify if the germination temperature, storage condition and period could influence rambutan seeds germination. The research were realized in two stages, corresponding to rambutan seeds storage management: after extracted from the fruits or kept in the fruits, until sowing. Storage condition were also evaluated: low temperature $\left(10^{\circ} \mathrm{C}\right)$ and room temperature, being realized the sowing at 0 (control), 3, 6, 9 and 12 days after storage, at different germination temperatures: $20,25,30,35$ and $40^{\circ} \mathrm{C}$. The seeds were placed in plastic containers with commercial substrate with pine, using four repetitions with 10 seeds for each. The percentage and period of germination were assessed. The experimental design was completely randomized and the data was evaluated by variance analysis, applying Tukey's test at $5 \%$ of significance for means with significant difference. According to the results, it is possible to conclude that the best temperature for rambutan germination is $25^{\circ} \mathrm{C}$ and the storage can be realized with the seeds inside the fruit until the time of sowing, in up tol six days.
\end{abstract}

Keywords: Nephelium lappaceum L., propagation, seedling obtaining, storage

The rambutan (Nephelium lappaceum L.) is a fruit that belong to the Sapindaceae family, originally from Malaysia, becoming one of the most important tropical fruit grown in Asia (Tindall, 1994). In Brazil, the mayor production is in Bahia and the largest consumer market is the São Paulo state. In the states of Bahia and Pará, Brazil, the rambutan is cultivated with excellent production performance and quality (Sacramento et al., 2009).

Under suitable conditions and without use of pruning, the plants can reach $12-20 \mathrm{~m}$ in height, with stem diameter from 40 to $60 \mathrm{~cm}$, and petiolate leaves, alternate and pinnate, with 2-4 pairs of leaflets arranged alternately or opposite in the rachis, with size ranging from 2 to $10.5 \mathrm{~cm}$ $x$ 5-28 cm, being the absence of terminal leaflet a gender characteristic. Inflorescences are erect, branched and with many flowers, being produced mainly at the ends of branches. Flowers are male (with only stamens well developed) or hermaphroditic (which can be basically female flowers, with small stamens, or male, with stigmas undeveloped). Fruits are produced in the end portion, in clusters, with 10 to 13 units (Corner, 1952; Valmayor et al., 1970).

The propagation methods used for this species can be using seeds, grafting and layering. Propagation by seeds is relatively easy and still the most used by producers (Hartmann et al., 2011). 
Some factors affect the seed germination, among them, the temperature can be very important because it had influence in the metabolic reactions, also affecting the seedling growth. According to the specie, the minimum, optimum and maximum temperatures are quite variable, and the optimum temperature, for the most of seeds, ranges between $25-30^{\circ} \mathrm{C}$ (Fachinello et al., 2005).

The seed storage is influenced by several factors related to initial seed quality (weather conditions during seed maturation, degree of ripeness at harvest, insect attack and diseases, degree of mechanical injury), and characteristics of the environment (seeds moisture content; air temperature; action of fungi and insects during storage and packaging) (Carvalho \& Nakagawa, 2012).

According to the review above and the lack of information regarding rambutan seedlings management, this research was realized aiming to verify if the temperature during germination and temperature and time during storage could influence rambutan seed germination.

The experiment was realized at the Laboratory of Fruit Seeds of the Department of Plant Production FCAV/UNESP, in Jaboticabal county, São Paulo state, Brazil. It was realized in two stages, corresponding to the rambutan seed storage: after extracted from the fruits and maintained inside the fruits until the sowing dates.

1) Seed storage after extraction from the fruits: the seeds were extracted immediately after the harvest of ripe fruits and placed in paper bags, kept at room condition (without control of humidity and temperature) and at low temperature $\left(10^{\circ} \mathrm{C}\right)$. The seeds were sown after 0 (control), 3, 6, 9 and 12 days of storage, at different temperatures: $20,25,30,35$ and $40^{\circ} \mathrm{C}$. Then the seeds were placed in plastic containers with commercial substrate with pine, in four repetitions with 10 seeds each, totalizing 1800 seeds.

The percentage and the germination period (in days) were evaluated, considering the emergence of normal seedlings, for seven weeks, until data stabilization.
2) Seeds storage inside the fruits: ripe fruits were collected and kept at room condition (without control of humidity and temperature) and at low temperature $\left(10^{\circ} \mathrm{C}\right)$. The seeds were extracted from the fruits only in the day of sowing: 0 (control), $3,6,9$ and 12 days after storage, being placed to germinate in plastic containers with commercial substrate with pine, at temperatures of 20,25, 30, 35 and $40^{\circ} \mathrm{C}$. Four replications were used, with 10 seeds each, totalizing 1800 seeds.

Percentage and germination period (in days) were evaluated, considering the emergence of normal seedlings, during eight weeks, until data stabilization.

The experiment was conducted in a completely randomized design for the two stages, the data were evaluated using analysis of variance, applying Tukey's test at $5 \%$ of significance when means were different.

According to the statistical analysis for all the treatments (Tables 1 to 4), it can be verified that the seeds stored at room temperature presented better germination rate when compared to those stored in a cold chamber (low temperature). Better germination rates were also obtained for seeds submitted to temperatures of 25 and $30^{\circ} \mathrm{C}$, observing, however, for the seeds germinated at $30^{\circ} \mathrm{C}$ the occurrence of a large number of abnormal seedlings, with excess of sprouting, which may be due to more intense cell division in higher temperatures.

At the storage period, for seeds extracted from the fruits (Table 1), can be verified better results with the absence of storage, or, in the other words, higher germination rates from seeds used immediately after the fruits extraction. For seeds kept in the fruit (Table 3), there is no significant difference between germination immediately after the extraction and storage for 3 days. For both studied situations, however, as the storage period increases, it can be observed a reduction in the germination rate.

Analyzing factors interaction, better results for the temperatures of 25 and $30^{\circ} \mathrm{C}$ (Tables 2 and 4) was observed, regardless the storage, differing significantly from the other temperatures and storage condition (low temperature). 
Table 1. Germination (\%) of rambutan seeds submitted to different temperatures, periods and storage temperatures, for seeds extracted immediately after the harvest of ripe fruit.

\begin{tabular}{|c|c|}
\hline Ambient (A) & Germination (\%) \\
\hline Without control & $38.30 \mathrm{~A}$ \\
\hline Low temperature & $30.89 \mathrm{~B}$ \\
\hline \multicolumn{2}{|l|}{ Temperature (T) } \\
\hline $20^{\circ} \mathrm{C}$ & $37.82 \mathrm{~B}$ \\
\hline $25^{\circ} \mathrm{C}$ & $51.29 \mathrm{~A}$ \\
\hline $30^{\circ} \mathrm{C}$ & $46.83 \mathrm{~A}$ \\
\hline $35^{\circ} \mathrm{C}$ & $36.96 \mathrm{~B}$ \\
\hline $40^{\circ} \mathrm{C}$ & $0.00 \mathrm{C}$ \\
\hline \multicolumn{2}{|l|}{ Days of storage (DS) } \\
\hline 0 & $63.88 \mathrm{~A}$ \\
\hline 3 & $52.02 \mathrm{~B}$ \\
\hline 6 & $37.71 \mathrm{C}$ \\
\hline 9 & $18.88 \mathrm{D}$ \\
\hline 12 & $0.46 \mathrm{E}$ \\
\hline \multicolumn{2}{|l|}{ F Test } \\
\hline A & $25.31 * *$ \\
\hline $\mathrm{T}$ & $151.31 * *$ \\
\hline DS & $238.05^{* *}$ \\
\hline $\mathrm{A} \times \mathrm{T}$ & $3.24 *$ \\
\hline$A \times D S$ & $5.45^{* *}$ \\
\hline TxDS & $18.71 * *$ \\
\hline$A \times T \times D S$ & 1.71 NS \\
\hline CV (\%) & 30.97 \\
\hline
\end{tabular}

Table 2. Statistical analysis for rambutam seeds germination percentage according to temperature and storage period and condition, for seeds immediately extracted after the harvest of ripe fruits.

\begin{tabular}{|c|c|c|c|c|c|}
\hline \multirow{2}{*}{ Ambient (A) } & \multicolumn{5}{|c|}{ Temperature (T) } \\
\hline & $20^{\circ} \mathrm{C}$ & $25^{\circ} \mathrm{C}$ & $30^{\circ} \mathrm{C}$ & $35^{\circ} \mathrm{C}$ & $40^{\circ} \mathrm{C}$ \\
\hline \multirow{2}{*}{$\begin{array}{l}\text { Without control } \\
\text { Low temperature }\end{array}$} & $40.09 \mathrm{~A} \mathrm{~b}$ & $54.63 \mathrm{~A} \mathrm{a}$ & \multirow{2}{*}{$\begin{array}{l}54.66 \mathrm{~A} \mathrm{a} \\
39.00 \mathrm{~B} \mathrm{ab}\end{array}$} & $42.09 \mathrm{~A} \mathrm{~b}$ & $0.00 \mathrm{~A} \mathrm{C}$ \\
\hline & $35.65 \mathrm{~B} \mathrm{~b}$ & $47.96 \mathrm{~B} \mathrm{a}$ & & $31.82 \mathrm{~B} \mathrm{~b}$ & $0.00 \mathrm{~A} \mathrm{C}$ \\
\hline \multirow{2}{*}{ Ambient (A) } & \multicolumn{5}{|c|}{ Days of storage (DS) } \\
\hline & 0 & 3 & 6 & 9 & 12 \\
\hline Without control & $63.88 \mathrm{~A} \mathrm{a}$ & $56.98 \mathrm{~A} \mathrm{a}$ & $46.24 \mathrm{~A} \mathrm{~b}$ & 24.39 A C & $0.00 \mathrm{~A} \mathrm{~d}$ \\
\hline Low temperature & $63.88 \mathrm{~A} \mathrm{a}$ & $47.07 \mathrm{~B} \mathrm{~b}$ & 29.19 B C & $13.38 \mathrm{~B} \mathrm{~d}$ & $0.92 \mathrm{~A} \mathrm{e}$ \\
\hline \multirow{2}{*}{ Temperature (T) } & \multicolumn{5}{|c|}{ Days of storage (DS) } \\
\hline & 0 & 3 & 6 & 9 & 12 \\
\hline $20^{\circ} \mathrm{C}$ & $80.00 \mathrm{~B} \mathrm{a}$ & $57.83 \mathrm{~B} \mathrm{~b}$ & $34.61 \mathrm{~B} \mathrm{C}$ & $6.91 \mathrm{BC} d$ & $0.00 \mathrm{~A} \mathrm{~d}$ \\
\hline $25^{\circ} \mathrm{C}$ & 85.39 A a & $75.88 \mathrm{~A} \mathrm{ab}$ & $62.78 \mathrm{~A} \mathrm{~b}$ & $32.42 \mathrm{~A} \mathrm{C}$ & $0.00 \mathrm{~A} \mathrm{~d}$ \\
\hline $30^{\circ} \mathrm{C}$ & $81.70 \mathrm{~A} \mathrm{a}$ & $67.23 \mathrm{AB} b$ & $48.62 \mathrm{ABC}$ & $34.32 \mathrm{~A} \mathrm{C}$ & $2.30 \mathrm{~A} \mathrm{~d}$ \\
\hline $35^{\circ} \mathrm{C}$ & $62.30 \mathrm{~B} \mathrm{a}$ & $59.17 \mathrm{~B} \mathrm{a}$ & $42.56 \mathrm{~B} \mathrm{~b}$ & $20.76 \mathrm{AB} C$ & $0.00 \mathrm{~A} \mathrm{~d}$ \\
\hline $40^{\circ} \mathrm{C}$ & $0.00 \mathrm{C} \mathrm{a}$ & $0.00 \mathrm{Ca}$ & $0.00 \mathrm{Ca}$ & $0.00 \mathrm{Ca}$ & $0.00 \mathrm{~A} \mathrm{a}$ \\
\hline
\end{tabular}


Table 3. Germination (\%) of rambutan seeds submitted to different temperatures, days and conditions of storage, for seeds stored inside the fruit.

\begin{tabular}{|c|c|}
\hline Ambient (A) & Germination (\%) \\
\hline Without control & $49.78 \mathrm{~A}$ \\
\hline Low temperature & $43.88 \mathrm{~B}$ \\
\hline \multicolumn{2}{|l|}{ Temperature $(\mathrm{T})$} \\
\hline $20^{\circ} \mathrm{C}$ & $50.90 \mathrm{~B}$ \\
\hline $25^{\circ} \mathrm{C}$ & $67.43 \mathrm{~A}$ \\
\hline $30^{\circ} \mathrm{C}$ & $66.50 \mathrm{~A}$ \\
\hline $35^{\circ} \mathrm{C}$ & $49.32 \mathrm{~B}$ \\
\hline $40^{\circ} \mathrm{C}$ & $0.00 \mathrm{C}$ \\
\hline \multicolumn{2}{|l|}{ Days of storage (DS) } \\
\hline 0 & $64.40 \mathrm{~A}$ \\
\hline 3 & $60.67 \mathrm{~A}$ \\
\hline 6 & $48.09 \mathrm{~B}$ \\
\hline 9 & $36.16 \mathrm{C}$ \\
\hline 12 & $24.82 \mathrm{D}$ \\
\hline \multicolumn{2}{|l|}{ F Test } \\
\hline$A$ & $11.186^{* *}$ \\
\hline $\mathrm{T}$ & $194.657^{* *}$ \\
\hline DS & $70.734^{* *}$ \\
\hline$A \times T$ & $3.840^{* *}$ \\
\hline$A \times D S$ & $3.938 * *$ \\
\hline$T \times D S$ & $6.133 * *$ \\
\hline $\mathrm{A} \times \mathrm{T} \times \mathrm{DS}$ & $1.72 \mathrm{Ns}$ \\
\hline $\mathrm{CV}(\%)$ & 26.63 \\
\hline
\end{tabular}

Table 4. Statistical analysis for germination percentage of rambutan seeds submitted to different temperatures, days and conditions of storage, for seeds stored inside the fruit.

\begin{tabular}{|c|c|c|c|c|c|}
\hline \multirow{2}{*}{ Ambient (A) } & \multicolumn{5}{|c|}{ Temperature (T) } \\
\hline & $20^{\circ} \mathrm{C}$ & $25^{\circ} \mathrm{C}$ & $30^{\circ} \mathrm{C}$ & $35^{\circ} \mathrm{C}$ & $40^{\circ} \mathrm{C}$ \\
\hline Without control & $60.26 \mathrm{Aab}$ & $70.96 \mathrm{Aa}$ & $68.24 \mathrm{Aa}$ & $49.21 \mathrm{Ab}$ & $0.00 \mathrm{AC}$ \\
\hline Low temperature & $41.53 \mathrm{Bb}$ & $63.89 \mathrm{Ba}$ & $64.77 \mathrm{Aa}$ & $49.44 \mathrm{Ab}$ & $0.00 \mathrm{Ac}$ \\
\hline \multirow{2}{*}{ Ambient (A) } & \multicolumn{5}{|c|}{ Days of storage (DS) } \\
\hline & 0 & 3 & 6 & 9 & 12 \\
\hline Without control & $64.40 \mathrm{Aa}$ & $63.87 \mathrm{Aa}$ & $57.64 \mathrm{Aa}$ & $37.96 \mathrm{Ab}$ & $25.02 \mathrm{AC}$ \\
\hline Low temperature & $64.40 \mathrm{Aa}$ & $57.47 \mathrm{Aa}$ & $38.54 \mathrm{BC}$ & $34.37 \mathrm{Abc}$ & $24.62 \mathrm{AC}$ \\
\hline \multirow{2}{*}{ Temperature (T) } & \multicolumn{5}{|c|}{ Days of storage (DS) } \\
\hline & 0 & 3 & 6 & 9 & 12 \\
\hline $20^{\circ} \mathrm{C}$ & $80.79 \mathrm{Aa}$ & $72.11 \mathrm{ABab}$ & $55.50 \mathrm{ABb}$ & $36.79 \mathrm{AC}$ & $9.31 \mathrm{BCd}$ \\
\hline $25^{\circ} \mathrm{C}$ & 85.39 Aa & $79.77 \mathrm{ABa}$ & $72.11 \mathrm{Aa}$ & $51.69 \mathrm{Ab}$ & $48.16 \mathrm{Ab}$ \\
\hline $30^{\circ} \mathrm{C}$ & 85.39 Aa & $84.38 \mathrm{Aa}$ & 69.70 Aa & $51.08 \mathrm{Ab}$ & $41.98 \mathrm{Ab}$ \\
\hline $35^{\circ} \mathrm{C}$ & $70.45 \mathrm{Aa}$ & $67.10 \mathrm{Ba}$ & $43.15 \mathrm{Bb}$ & $41.25 \mathrm{Abc}$ & $24.67 \mathrm{BC}$ \\
\hline $40^{\circ} \mathrm{C}$ & $0.00 \mathrm{Ba}$ & $0.00 \mathrm{Ca}$ & $0.00 \mathrm{Ca}$ & $0.00 \mathrm{Ba}$ & $0.00 \mathrm{Ca}$ \\
\hline
\end{tabular}

Storage period in function of the ambient result in higher rates of germination until three days of storage at ambient condition when the seed is placed for storage after extracted from the fruit (Table 2). When the seeds were kept inside the fruit for storage, it can be verified, when maintained at room temperature, similar germination rates until six days of storage and, when using the cold chamber, until three days of storage (Table 4).

Analyzing the interaction between time of storage and germination temperature, for seeds extracted from the fruits (Table 2), better results can be observed for the temperatures of 25 and $30^{\circ} \mathrm{C}$. For $25^{\circ} \mathrm{C}$, higher seed germination is observed until 6 days of storage, for seeds stored inside the fruit (Table 4), where can be observed better germination rates at 25 and $30^{\circ} \mathrm{C}$, and the 
seeds can be stored up tol 6 days.

An important aspect to be considered in the production process of any culture is the maintenance of seed quality during the storage period, being a determinant factor to achieve productivity (Pereira \& Pasqualeto, 2011 ), as showed in this research with rambutan. The storage, knowledge about the longevity, as well as sensitivity to cold, are important to program the proper storage method and the species conservation factors (Nascimento \& Carvalho, 2012). In the germination process, as can be verified in this research with germination for rambutan seeds, the temperature is the environmental factor that has the higher influence, being able to accelerate, reduce and even suppress the emission of the primary root, as it is directly related to chemical reactions that occur right after the absorption of water by the seed (Carvalho \& Nakagawa, 2012).

In a research with araçá (Psidium cattleyanum), the authors observed that seeds stored in the refrigerator presented $90 \%$ of germination (Tomaz et al., 2011), differing from the data of the present research, since the storage of rambutan seeds at low temperature can led to a considerable decrease in the germination rate. However, the sensitivity to low temperature storage was also reported for cupuí (Theobroma subincanum) seeds, presenting loss of viability when exposed to a temperature of $7^{\circ} \mathrm{C}$ during 8 hours (Nascimento \& Carvalho, 2012).

For the germination temperature, a factor previously described and reported as important and fundamental, the indication for rambutan is at $25^{\circ} \mathrm{C}$, comparing with that observed in a study with ingá (Inga ingoides), where the authors described a similar germination, alternating temperatures of $20-30^{\circ} \mathrm{C}$ and for the temperature of $30^{\circ} \mathrm{C}$ (Nascimento et al., 2011 ).

Studying the seed storage of Myrciaria caulifora and germination at different temperatures, Danner et al. (2011) observed loss of viability ( 5 days), as reported in the present research with rambutan, denoting behavior of recalcitrant seeds. The authors also observed that Myrciaria cauliflora germination presents higher loss of seed viability at low temperatures $\left(12^{\circ} \mathrm{C}\right.$ and $\left.6^{\circ} \mathrm{C}\right)$. In a study with tamarind, it was observed that the seeds can be conserved until 13 months, under refrigeration (Queiroz, 2010). However, similar to the result observed in the present research with rambutan, the seeds of jackfruit exhibit lower germination after storage, and the deleterious effect increases progressively during the storage, being recommended the sowing immediately after seeds removal from the fruits (Silva et al., 2013). The influence of the temperature on seed germination of fruit species has been widely studied, being possible to know a little more about the characteristics of each specie and suitability for cultivation or production of seedlings in certain locations and seasons. Experiments demonstrated different responses according to the species, and it was observed a wide adaptation according to temperature for the emergence of Eugenia species seed germination, with germination and development of normal seedlings from 20 to $30^{\circ} \mathrm{C}$, being the seeds indifferent to alternating temperature (20/30 and $20 / 35^{\circ} \mathrm{C}$ ) (Lamarca et al., 2011). Guabiroba (Campomanesia xanthocarpa) seeds presents higher rates of germination at temperatures of 25 and when alternating temperatures of $20-30^{\circ} \mathrm{C}$ (Gomes et al., 2016). Best results for cupuaçu (Theobroma grandiflorum (Willd. Ex. Spreng.) Schum) seeds were observed when submitted to a temperature of $30^{\circ} \mathrm{C}$ (Ferraz et al. 2012), being also observed for Sebastiania brasiliensis (Bassaco et al., 2014) and for jaboticaba tree (Dias et al., 2011).

According the obtained results, it can be concluded that the best temperature for rambutan seed germination is $25^{\circ} \mathrm{C}$ and, if the seeds are submitted to storage inside the fruit until sowing, it could be realized until 6 days.

\section{Acknowledgements}

The authors gratefully thank FAPESP, for the project research support (Process number 2011/20034-1).

\section{References}

Bassaco, M.V.M., Nogueira, A.C., Cosmo, N. 2014. Avaliação da germinação em diferentes temperaturas e substratos e morfologia do fruto, semente e plântula de Sebastiania Brasiliensis. Floresta 44: 381-392. 
Carvalho, N.M., Nakagawa, J. 2012. Sementes: ciência tecnologia e produção, 5. ed. Funep, Jaboticabal, Brasil. 588 p.

Corner, E.J.H. 1952. Waysude trees in Malaya. 2. ed. Govt Printing office, Singapore, Malaysia. 592 p.

Danner, M.A., Citadin, I., Sasso, S.A.Z., Ambrosio, R., Wagner JR, A., 2011. Armazenamento a vácuo prolonga a viabilidade de sementes de jabuticabeira, Revista Brasileira de Fruticultura 33: 246-252.

Dias, M.A., Lopes, J.C., Souza Neto, J.D., Heberle, E. 2011. Influência da temperatura e substrato na germinação de sementes de jabuticabeira (Myrciaria caulifora Berg.). Idesia 29: 23-27.

Fachinello, J.C. 2005. Propagação de plantas frutíferas. Embrapa Informação Tecnológica/Embrapa Uva e Vinho, Bento Gonçalves, Brasil. 221 p.

Ferraz, I.D.K., Albuquerque de, M.C.F., Calvi, G.P., Farias de, D.L. 2012. Critérios Morfológicos e temperatura para avaliação da germinação das sementes de cupuaçu. Revista Brasileira de Fruticultura 34: 905-914.

Gomes, J.P., Oliveira, L.M., Ferreira, P.L., Batista, F. 2016. Substratos e temperaturas para teste de germinação em sementes de myrtaceae. Ciência Florestal 26: 285-293.

Hartmann, H.T., Kester, D.E., Davies, J.F.T., Geneve, R.L. 2011 . Plant propagation: principles and practices. 8. ed. Prentice Hall, New Jersey, USA. $915 \mathrm{p}$.

Lamarca, E.V., Silva, C.V., Barbedo, C.J. 2011. Limites térmicos para a germinação em função da origem de sementes de espécies de Eugenia (Myrtaceae) nativas do Brasil. Acta Botanica Brasilica 25: 293-300.

Nascimento, I.L., Leal, C.C.P., Nogueira, N.W., Medeiros, A.K.P., Câmara, F.M.M. 2011. Influência de diferentes tipos de substrato e temperatura na germinação de sementes de Inga ingoides (RICH.) Willd. Revista Verde 6: 0710.

Nascimento, W.M.O., Carvalho, J.E.U. 2012. Sensibilidade de sementes de Cupuí (Theobroma subincanum) à redução do grau de umidade e a exposição à baixa temperatura. Revista Brasileira de Fruticultura 34: 915-920.
Pereira, M.E.., Pasqualeto, A. 2011. Desenvolvimento sustentável com ênfase em frutíferas do Cerrado. Estudos 38: 333-363.

Queiroz, J.M.O. 2010. Propagação do tamarindeiro (Tamarindus indica L.). $78 \mathrm{f}$. (Dissertação de Mestrado) - Universidade Federal do Recôncavo da Bahia, Cruz das Almas, Brasil.

Sacramento, C.K., Luna, J.V.U., Muller, C.H., Carvalho, J.E.U., Nascimento, W.M.O. 2009. Rambotã. In: Santos-Serejo, J.A., Dantas, J.L.L., Sampaio, C.V., Coelho, Y. da S. Fruticultura Tropical- Espécies Nativas e Exóticas. Embrapa, Brasília, Brasil. p. 403-421.

Silva, J.V., Oliveira, R.J., Silva-Matos, R.R.S. 2013. Emergência de sementes de jaqueira (Artocarpus integrifolia) submetidas à secagem e armazenamento. Revista Agrarian 6: 514-518.

Tomaz, Z.F.P., Galarça, S.P., Lima, C.S.M., Betemps, D.L., Gonçalves, M.A., Rufato, A.R. 2011. Tratamentos pré-germinativos em sementes de araçazeiro (Psidium cattleyanum Sabine L.). Revista Brasileira de Agrociência 17: 60-65.

Tindall, H.D., Meninin, U.G., Hodder, A.J. 1994. Rambutan cultivation. FAO, Rome, Italy. 182 p. (FAO plant production and protection paper n. 121).

Valmayor, R.V., Mendoza, J.R.D.B., Aycardo, H.B., Palencia, C.O. 1970. Growth and flowering habits, floral biology and yield of rambutan (Nephelium lappaceum Linn.). Philippines Agriculture 54: 359-374. 